\title{
Multi-proxy evidence of rainfall variability recorded in subaqueous deltaic deposits off the Adra River, southeast Iberian Peninsula
}

\author{
I. Mendes ${ }^{\text {a, }}{ }^{*}$, F.J. Lobo ${ }^{\text {b }}$, L.M. Fernández-Salas ${ }^{c}$, N. López-González ${ }^{\text {d }}$, P. Bárcenas ${ }^{\text {e }}$, \\ J. Schönfeld ${ }^{f}$, Ó. Ferreira ${ }^{a}$ \\ a CIMA, Universidade do Algarve, Campus de Gambelas, 8005-139 Faro, Portugal \\ ${ }^{\mathrm{b}}$ Instituto Andaluz de Ciencias de la Tierra (CSIC-Universidad de Granada), 18100 Armilla, Granada, Spain \\ c Instituto Español de Oceanografía, Centro Oceanográfico de Cádiz, 11006 Cádiz, Spain \\ d Instituto Español de Oceanografía, Centro Oceanográfico de Málaga, 29640 Fuengirola, Spain \\ e Dpto. Análisis Matemático, Facultad de Ciencias, 29080 Málaga, Spain \\ ${ }^{\mathrm{f}}$ GEOMAR Helmholtz-Zentrum für Ozeanforschung Kiel, Germany
}

\section{A R T I C L E I N F O}

\section{Article history:}

Received 6 October 2014

Received in revised form 1 June 2015

Accepted 5 August 2015

Available online $\mathrm{xxx}$

\section{Keywords:}

Climatic variability

Benthic foraminifera

Geochemistry

Deltaic environments

Human impact

Northern Alboran Sea

\begin{abstract}
A B S T R A C T
The Adra River deltaic system, southeast Iberian Peninsula, shows a steep topography and is subjected to strong climatic seasonality. This system has been affected by alternating wet and dry periods, and it has also undergone numerous anthropogenic activities such as deforestation, mining activities, river channel deviations and dam construction, particularly during the last two centuries. Two sediment cores were retrieved off the Adra River, from the western (MS_V9) and eastern (MS_V4) lobes of the subaqueous deltaic deposit. A multi-proxy study was carried out, including grain size, benthic foraminiferal assemblages, magnetic susceptibility and geochemical element analyses, in order to understand the sedimentary expression of recent climatic cycles and anthropogenic interventions in the river basin.

Periods of increased deposition of coarse-grained sediments, low absolute abundance of benthic foraminifera and high elemental ratios indicative of terrigenous contributions, were interpreted as periods of increased sediment supply to the shelf. Four flooding events were recorded in core MS_V9 and three events on core MS_V4, of which two were observed in both cores. They were related to periods with major floods that were documented on the southern Iberian Peninsula around 1770-1810 and 1860 $-1870 \mathrm{AD}$. On the other hand, sediment core intervals exhibiting increasing proportion of fine-grained sediments and higher abundances of foraminiferal species assigned as successful colonizers (Textularia earlandi) and opportunistic species that feed on bacteria or terrestrial organic matter (Bolivina ordinaria, Bulimina elongata, Eggerelloides scaber and Ammonia beccarii or tepida), indicate the establishment of new environments with new ecological constraints. They were related to significant decreases of terrigenous sediment input during low rainfall or dry periods. The increase of opportunistic species feeding on fresh phytodetritus (Nonionella iridea, Nonionella stella, Nonionella sp., Brizalina dilatata, Epistominella vitrea and Bolivinellina pseudopuntata), under more stable environmental conditions, also point to a stronger marine influence on the prodeltaic environments during these periods. The human interventions on the river basin after $1872 \mathrm{AD}$, with the deviation of the main river channel to the east, led to a drastic reduction of the sediment exported to the western delta lobe. This study showed that the sedimentation on the Adra subaqueous deltaic deposit was mainly controlled by rainfall variability from 1663 to 1872 $\mathrm{AD}$, and afterwards by anthropogenic interventions.
\end{abstract}

๑) 2015 Elsevier Ltd. All rights reserved.

\footnotetext{
* Corresponding author.

E-mail address: imendes@ualg.pt (I. Mendes).
}

\section{Introduction}

High-frequency paleoenvironmental changes may be recorded in subaqueous deltas during their different evolutionary phases, and therefore these systems can be used as very high-resolution environmental archives. These environmental changes are usually 